\title{
ECONOMIC AND SOCIAL TENSIONS IN IMAGE-BUILDING OF SOCIAL ENTERPRISES IN POLAND
}

\author{
Ewa Bogacz-Wojtanowska*, Sylwia Wrona**
}

\begin{abstract}
Background. The image of the organisation is a collection of subjective notions and beliefs about the organisation, held by its recipients. A negative or positive perception of the organisation by its external or internal environment is influenced by its entire operations. Therefore, intentional image-building and launching public relations activities requires using certain tools and methods.

Research aims. The purpose of this study is identifying the ways of image-building used by social enterprises in Poland. The authors focus in particular on what attitude the leaders of enterprises have towards building the organisation's image, what methods they use and whether they research organisational effectiveness in the area of image-building.

Methodology. The presented findings are the result of a qualitative analysis. The data was collected using the following research methods: in-depth individual interviews, observations, and analyses of documents. The research which partial findings are presented in this study was carried out in 2012 and 2013 within the project entitled Integrated support system of social economy.

Key findings. The results of the qualitative research prove that despite the enterprises' awareness concerning the need to create their image, they often do not undertake any planned efforts to fulfil this objective.
\end{abstract}

Keywords: organisation image, public relations, social enterprises.

* Jagiellonian University in Cracow. E-mail: ewa.bogacz-wojtanowska@uj.edu.pl

** Jagiellonian University in Cracow. E-mail: sylwia.wrona@doctoral.uj.edu.pl 


\section{INTRODUCTION}

The issues of media and public image of social enterprises' activities in Poland have not had their own literature, yet. There are several reasons for this state of affairs. Firstly, so far, we still know little about image-building by NGOs which are the natural backing and the basis of development for social enterprises in Poland. Secondly, social enterprises are an organisational phenomenon that de facto has been developing in Poland for over a decade. Of course, the so-called old social economy existed in Poland (Rymsza, 2008), but its organisations - traditional cooperatives - were formed in entirely different social and economic circumstances. So, thirdly, the research on social enterprises is in its initial stage, and the issue of their image is not well explored. Therefore, the objective of this study is identifying the ways in which social enterprises in Poland create their image. The main research questions we would like to investigate in the paper are: what attitude the leaders of enterprises have towards building the organisation's image and what methods they apply and what tools they use.

\section{LITERATURE REVIEW - THE IMAGE IN THE RESEARCH ON ORGANISATIONS}

The term "image" signifies a picture, a portrait, a likeness (Tokarski, 1980, p. 808). The image of an organisation means the notion of the environment, its stakeholders, what a particular organisation is about, or more broadly, an array of convictions and thoughts about the organisation, treated as an element of organisational value $(\mathrm{Bu}-$ kowiec, 2005, p. 28). The image of an organisation in the awareness of its recipients is always subjective; it constitutes the product of the organisation's activity, and traits and notions of the people on whom it is oriented (Kotas, 2014, p. 134).

Building the image of an organisation is often equated with Public relations activities, which is a marketing tool, treated also as shaping, changing, and repairing the image of an organisation in its environment (Fraczek, 2011, p. 116). The objective of PR is "acquiring approval and favour for the activities of the organisation in the local community, among its future beneficiaries, potential sponsors, and partners" 
(Bielińska-Kuniszewska \& Demitrewicz, 2012, p. 4). Public relations is an important marketing tool as well (Kocon, 2013, p. 83); it is also a function of management that helps to fulfil strategic goals, a form of communication between the organisation and its environment, activities leading to the identification of the image of the organisation in the community, achieving the desired image and reputation, and then maintaining it, and finally, planned, long-term activities (Smektała, 2006, p. 11). Public relations and image-building of the organisation requires using certain methods and tools. The tools most commonly used for this purpose are: events, speakers' bureaus, press releases, sponsoring, and newsletters (Henley et al., 2001, p. 163). In order to intentionally shape their image, with increasing frequency, contemporary organisations use new technologies and the Internet. In the research and analysis of the image of a given enterprise functioning in the environment, similar methods are used as in advertising, i.e. "press monitoring, projective methods, word association tests, gap filling, visual collage, as well as techniques such as brand party, bubbles diagram, brandsights-core, PCD - perceptual circle diagram" (Witczak, 2013 , p. 84), as well as similar measuring methods. Traditional media are still used for creating the organisation's image, but increasingly often it is recommended to acquire trusted and engaged audience via the Internet, and above all - through the social media (Stopczyńska, 2014, p. 268).

The social economy sector, i.e. socio-economic organisations which belong neither to the traditional for profit sector (market economy) nor to the public sector (government) rather act at the interface of civic society and markets (Defourny, 2001; Young, 2007; Jäger, 2010). The main goal of these organisations, called 'social enterprises' is doing business for socially useful purposes (Zappala, 2001). Social economy in public discourse is a space where non-financial exchange and ethical trade take place and enterprises operate for the local community. Social business is based on collective, internal, and inter-organisational solutions, horizontal and non-hierarchical networks, where harmony, cooperation, social value, active citizenship as well as the value of each person and enterprise constitute value (Mendell, 2009; Amin, 2009; Lechat, 2009). Therefore, we can assume that in creating image, social enterprises will have organisational and management features and behaviours resembling both NGOs as the representation of civic society, and enterprises. It should also be added that there are 
no empirical findings pertaining strictly to image-building by social enterprises (Bogacz-Wojtanowska et al., 2014).

An enterprise can achieve competitive advantage thanks to having a positive image in the community (Pawlak-Kołodziejska, 2011, p. 527). Enterprises aim to create, emphasise, and preserve a brand that would be popular and unique (Kostera, 2008, p. 399). It is an important issue, impacting the final success and viability of the organisation. A positive image of the organisation draws the attention of the society, gradually winning it over, reinforces the loyalty of the recipients and employees, increasing motivation of the latter group to work, and it is a guarantee of a greater stability of the organisation's functioning, and above all - it makes the organisation recognisable (Pawlak-Kołodziejska, 2011, p. 528). One of the objectives of such an intentional building of the organisation's image, products, or services, is "eliciting positive reactions" among the audience, to enlist their financial and emotional support (Jemielniak et al., 2014, p. 292). It is important that organisations pay attention to the fact that "means of communicating image (as well as message) must be suited to the specificity of the audience to which the message is addressed. The point is to select the medium that would reach the particular group best and is preferred by it" (Jemielniak et al., 2014, p. 293).

An important factor influencing the image of a non-governmental organisation is the general image, reputation, or notion of NGOs present in the society (Hubert-Brzezińska \& Olszówka, 2008, p. 9). It means that all information concerning organisational pathologies, scandals, or NGOs' unethical activities contribute to the reinforcement of the existing stereotypes about them and project on both the image of the entire third sector and particular organisational entities that operate within it. An inconsistent, negative, and unreliable image of an organisation "results in the decrease of society's trust, and lack of social legitimization", while it negatively affects the opportunity for cooperation and resource acquisition (Bogacz-Wojtanowska, 2013, p. 122). Among problems of NGOs concerning image-building, the following can be discerned: insufficient public education and misunderstanding of organisations' activities, lack of successful communication of the work they perform, limited use of their capacities in terms of uniting and involving the society, as well as low awareness of the society. These areas where NGOs' challenges are visible, often become the objectives of PR activities (Łukasiuk, 2014, p. 49). When building their 
image, NGOs must also refer to the changes in the environment, i.e. in particular increasing needs of social groups, advancing globalisation, and growing competition for financial resources within the third sector (Mort et al., 2002, p. 77). Therefore, the efficiency in fundraising and fulfilling their mission depends on establishing a strong image position and a brand that commands trust, and is capable of reaching various types of audience (Laidler-Kylander et al., 2007, p. 274). In the case of NGOs, important aspects of image-building are transparency and integrity, as well as visible results of their activity (Adamiak, 2015, p. 6).

\section{RESEARCH METHODOLOGY}

The research which partial findings are presented in this study was carried out in 2012 and 2013 within the project entitled "Integrated support system of social economy".* Its primary goal was to identify the factors of social enterprises' viability in Poland, i.e. such organisational features and phenomena in their environment that could contribute to their development, sustainability and success. A particularly interesting issue was the identification of their image-building ability that would contribute to their faster development.

The objective of the part of the research presented in this study was to identify how social enterprises in Poland create their image in the community, and in particular, what tools and methods they use and how they recognise whether the image they have is satisfactory and contributes to the realisation of social and economic goals.

The main research questions we are trying to answer in this study are as follows:

- How Polish social enterprises build their image in the community, who in the organisation is responsible for it and to what extent is this a formalised and systematic process?

- Who is responsible for image-building in these enterprises and how do they approach the task?

* Research was conducted by the Institute of Public Affairs Foundation (the co-author of the paper participated in it, which is elaborated on later in the text) within a project: "Integrated support system of social economy" under Human Capital Operational Programme, Priority I. Employment and Social Integration, Measure 1.2 System support to institutions of social assistance and integration. The project was co-financed with European Union resources under the European Social Fund and conducted in the years 2009-2014. 
- What methods and tools enterprises use to develop or reinforce their image?

The project research was carried out in the years 2010-2013 and it was divided into three phases. In the first phase, carried out in late 2010 and 2011, 36 subjects were selected for the study. The objective of this phase was the characterisation of enterprises, their rooting, social capital, and legal environment. The second phase, realised in the first half of 2013, encompassed organisational and management issues, as well as sustainability and success factors of social enterprises. The third and final phase, which results are presented in this study, carried out in the second half of 2013, involved 28 entities and focused mainly on competitivity factors of social enterprises and their functioning in the local community. We were also seeking answers to questions concerning image-building by the studied enterprises. Enterprises were purposefully selected and included social enterprises that:

- belonged to the so-called new social economy (most legislative initiatives and support systems are addressed to entities created after 1989 within the third sector),

- had various social objectives,

- conducted their economic activity in various areas (including service providers, but also manufacturers),

- had varied organisational forms (social cooperatives (20), Vocational Development Centres (2), NGOs conducting business activity [foundations (2) and associations (8)], non-profit companies (2) and church organisations conducting business activity (2)).

The research was a qualitative study - each of the selected social enterprises constituted a separate case study. Case study is a research strategy focused on understanding the processes happening within a particular case study, arrangement (Eisenhardt, 1989). Case studies can be based on a single or numerous cases and concern various levels of analysis (Yin, 1984). The decision to apply this approach to the study resulted from the adopted research premises within the entire executed project, as well as the research goals adopted in the last phase of the study. In order to collect data from each enterprise, three research methods were used:

- in-depth interviews with the leaders, managers, representatives, employees and stakeholders of social enterprises, according to the prepared script, 
- observations in enterprises carried out according to the prepared observation key during visits in organisations,

- analyses of organisational documents, acquired during visits in enterprises (financial reports and balance sheets, business plans, regulations, etc. as well as portfolios and websites of organisations).

The results of the research on the creation of social enterprises' image presented here are the product of a qualitative analysis. We were looking for particular regularities and attempted to explain problems connected with the image of social enterprises. The basic analysis consisted of searching for similarities and differences between the analysed cases, and specifying selected categories.* The analysis consisted of multiple readings of every case study, together with gradual categorisation of data and its comparison. It enabled introducing certain generalisations as explanations which, however, have no claim to universality. It should be also noted that particular case studies were prepared by different researchers, studying social economy entities according to strictly defined procedures and research tools. At the same time, they conducted a preliminary data selection within each study. Therefore, the results presented here take the form of a secondary analysis.

\section{RESULTS}

\section{The awareness of the need to shape the image of a social enterprise}

The vast majority of the studied enterprises of social economy realise the need to build and reinforce their image among the recipients of services, customers, and all groups of stakeholders. Nevertheless, not all of them manage to set and achieve their image goals. Certain leaders of enterprises, especially of those that have been present on the market for several years, noted the fact that their activity evoked the most interest in the first phase of their operations, right after the launch of their operations, when the stakeholders, especially public organisations, were significantly interested in cooperation. As a kind

* All of the analysed social enterprises were numbered from 1 to 36. 
of novelty in the local community, they were invited to various kinds of events, fairs, and conferences. In many cases, despite losing the novelty effect, they managed to maintain the activity. Leaders of enterprises interpret the phenomenon in two ways: as the tendency of local authorities to improve their own image and build social capital, but more often, as the opportunity to promote their own work and relatively easy acquisition of future co-operators, and possible promotion of their activities thanks to the execution of commission for certain services and RFQs issued by particular public institutions:

We were in Cracow, at meetings with the Social Economy and there we met our vice-president - Mr. X. He welcomed us cordially and said, "You know, I was just talking about you" (Enterprise 13*).

Initially, social enterprises received support from local public organisations (especially community or municipality offices), often very interested in their development due to innovative solutions to social problems, or the chance to obtain financial resources to spend for the benefit of the local community. This help included also the promotion of their activities, the aforementioned conferences, and commissions for products and services:

Not only an ordinary resident, but also the city council that once helped us, voted in favour of this grant. (...) We try to help them in some way, e.g. by participating in local festivals - we help each other and this is also always some form of advertising for us, when we make a banner for them, or leaflets, posters, or we plaster something, etc. (Enterprise 1).

Leaders of the organisation are usually the ones feeling responsible for creating the image, although in social cooperatives, members are encouraged to be active in this respect. However, usually the image-building activity is carried out by the way, ad hoc, normally outside of the basic activities connected to the management of the organisation. Most of the time, enterprises do not have an image-building strategy or a plan, relying either on institutional activities or the expectation that work performed well and solidly will contribute to the positive reception of their organisation:

* All of the analysed social enterprises were numbered from 1 to 36 . The quotes are from interviews in each enterprise. 
We are constantly making all our employees aware that by their attitude and commitment to work they also influence the way our organisation is perceived by the external environment (Enterprise 2).

These enterprises that decide they have a positive image in the community focus on preserving and reinforcing the already gained trust, even though it is not an easy task, since often a difficult economic situation and challenges with regard to maintaining financial liquidity push the work on the relationship with the community to the background:

Image-wise, everything was done so that we were perceived as a professionally created company from the very beginning - from planning the logo, to marketing, and development strategy. But we feel a dissonance between the image and the continuously difficult economic situation (Enterprise 4).

Equally important is the fact that trust towards an enterprise, and as a result - the image they consider to be positive, are the outcome of trust towards the leader or the group of people who create the organisationowing to the non-governmental past, strong local activity, involvement for the community, usually within an NGO that later incubated the social enterprise. By building social economy, active and committed leaders transmit a part of their established image to the organisation. Among those that achieved success, enterprise leaders distinctively emphasised systematic and targeted (albeit not formalised) activities in terms of image-building and establishing the awareness in society not just as an enterprise, but also an organisation that achieves particular social objectives. Others indicate the success in terms of establishing the image and emphasise that they focus on reinforcing and creating the brand, as in this area they managed to achieve the recognisability of the enterprise, its products, and social activities:

Among local cooperatives, we are one of the most socially active ones. We try to go to many places, give people tips and inspire them to action. [...] And in cooperation with other people who do this kind of work, we'd like to launch more such cooperatives in Wrocław, particularly in the Nadodrze district (Enterprise 12).

The success in terms of image and the success of the enterprise would not be possible in the case of certain social enterprises without real 
changes in local communities, visible for stakeholders. In the case of one of the largest entities of social economy in Poland and worldwide, the initial reluctance turned into acceptance with an increase in the number of job opportunities, an improvement in the quality and level of life, thanks to the enterprise's activities. It should be added that among the studied entities, there were also those that practically did not perform any image-related actions.

\section{Leaders as reputation builders in social enterprises}

As it has already been stated, leaders are the most often indicated people responsible for image-building. There are leaders who try to involve their entire team in a joint effort to fulfil the goals concerning the popularisation of the organisation and work on its positive image. However, despite the often-verbalised awareness of the significance of systematic image-building activities for the success of the enterprise, leaders rather indicate tools that serve them for marketing purposes (e.g. the Internet, social media, participation in exhibitions) than methods or actions in this respect. However, in the majority of the studied cooperatives, issues of joint work on the image were accentuated.

At the same time, traits and behaviours of leaders in many of the studied social enterprises predestined them to represent the organisation. Sometimes professional image-building by the leader is not entirely possible, since they do not possess such skills. Some of the studied leaders noted the duality of objectives that social economy entities have, i.e. the necessity to possess competences useful in market operations, or the entrepreneur's vision and simultaneously those that support understanding and achievement of social objectives. Meanwhile, among leaders of social economy there are often people who along the way of an NGO's development created an entity of social economy without having entirely sufficient knowledge and competences to function on the market. It is important to note that certain leaders expressed reflections concerning building and using networks and their own contacts to build the success of their enterprise.

At the same time, leaders notice serious barriers, which make it difficult to create the reputation they expect. First of all, social cooperative leaders see the pejorative connotations of the term "social cooperative" which is often associated with poverty, exclusion, and an organisation which has not much to do with business success in general: 
There were problems in terms of a bad reception of the name "social cooperative". Now, the term has become more rooted, but still we have a marketing name introduced about a year ago (Enterprise 1).

I definitely don't like the name - social cooperative. I would definitely change that. It simply has really bad connotations. And many people, when they hear it, associate it with a Social Welfare Centre and don't want such products. While this is a normally functioning company (Enterprise 2).

Other indicated problems included insufficient staff, resulting in the inability to undertake image oriented actions. In the opinion of most researched enterprise leaders, forming the image is important, but at the same time they have serious objections as to the possibility of introducing such actions in their organisations, as the employees or other staff members have their own responsibilities.

And finally, the identified problem in terms of image. In some social enterprises it concerned unpopular social goals, for example support for drug addicts or other socially excluded people. This problem concerns those enterprises which incubated from nongovernmental organizations, and "inherited" the social goals.

\section{Methods and tools of image-building in social enterprises}

Most of the studied entities are aware of the significance of image-building for the development of their own organisations. However, not all of the enterprises included in the research consistently make image-building efforts to an equal degree. Therefore, it is possible to note certain divergences in the repertoire of methods used and tools that help to build and preserve the image of an organisation in the community.

In order to create image, the studied enterprises most frequently use: leaflets, brochures, catalogues, websites, social media, and gadgets. However, they also work more broadly, they organise actions addressed to the local community (discounts, bonuses), they support the local culture, they relate their operations to the tradition and history of the region, support local residents by offering them jobs and supporting entrepreneurship, they promote civic attitudes, activate youth and revitalise space. The promotion of the image is facilitated by various types of events, debates, fairs, and conferences; participation in such events is most often a chance for the organisation to establish relationships that may also result in cooperation: 
We went to the [...] Days, a two-day open air event in Piaseczno. We could exhibit, present, and come with our catalogues and leaflets (Enterprise 14).

The set of tools used varies depending on the enterprise's attitude: from exiguous or incidental activities, to systematic and continuous actions. It is important to note that marketing activities are often connected with public relations; they are neither differentiated nor separated within the enterprise. While it is true that larger, more developed social enterprises employ marketing specialists, activities aiming at improving the enterprise's reputation are carried out also within marketing activities. Similarly, the studied enterprises, combine image-building based on the achievement of social objectives, and use economic goals.

An important element of image-building in the studied social enterprises is the question of creating the space. This pertains mainly to entities that provide services, which constitute the vast majority of the enterprises included in the research. Building a place, a space where the enterprise operates, can have two dimensions: one concerning the place - the venue, and the broader one - the entire community: the village, town, or commune. In the first case, of mostly small social enterprises, the question is preparing an attractive and distinctive venue, a friendly and inviting place with an extra offer that is often an element of achieving social objectives.

Our café has such a nice program of meetings, workshops, open debates, and film shows. We are creating a place where we can work together and exchange inspirations (Enterprise 12).

In the second case, the creation concerns the community, and it takes place in large social enterprises. Their activities for the improvement of the environment, the landscape, jobs, and other areas of the community's life are the best way to uphold the reputation, especially in the local community:

That's a shame that there are no photos of how it all looked here, a shabby town with scruffy fences falling over. The sense of hopelessness was evident. It needed someone with a vision, and the courage to execute it (Enterprise 19).

The studied social enterprises also use winning awards as an image-building tool. It is connected with prestige, credibility, and 
recognition of the organisation's brand by the recipients. Such a promotional tool usually expands the audience:

Our project in Brussels won the prize in social economy for the construction of a social enterprise (Enterprise 14).

It is interesting to note that during the research, only certain enterprises indicated the necessity of building image through media. Others enjoyed the interest of local press in the initial phase of their operations and managed to maintain it. Only a few really used media sporadically, and even less frequently used social media in the research period. Actually, only one enterprise communicated with its customers in a significant way in this manner, especially via Facebook and Twitter:

Additionally, we should remember about the presence of the hostel and the café online and in the social media. Our fanpage in the service, very active and full of materials from various events, was liked by 815 people (...) (Enterprise 23).

\section{CONCLUSION}

The most important findings of the research are as follows:

1. The short experience of new social economy in Poland is the reason why social enterprises do not have good role models for reputation building. Most of the social enterprises' leaders in the study realise the necessity of caring for the image and working to reinforce it. However, the scope of the professionalisation of activities is very diverse. Attitudes vary from a complete disregard for the issue of the image to professional actions carried out according to outlines planned in advance.

2. Image-building efforts of most entities are on and off, short-term and lacking the basic analysis of the environment or formulated image goals. A part of the activities is made intentionally, another part entirely intuitively and accidentally.

3. Some of the studied enterprises believe that it is important to use temporary popularity and the "freshness effect", the novelty on the market. This knowledge can be used, but some enterprises emphasised that they had overlooked this "novelty effect" entirely. Certain enterprises treat the strong interest in 
their activities right after they were created, especially on the part of local authorities that invited them to numerous fairs, conferences, and councils, as local authorities trying to take credit and easily benefit from their work. Other regard it as an opportunity for, among others, promotion and acquisition of new customers, and institutional partners for the execution of the planned initiatives. Thus, they try to impact the integration of the local community around the social objective which is improving the resident's quality of life.

4. It can be noted that enterprises which are strong and durable in terms of identity, do not need support in creating or preserving their image, and the new ones readily use the help of local public institutions.

5. Organisation leaders are usually involved in intentional image-building, but they emphasise that they try to involve the entire team, because they often want to be perceived as an entity open to cooperation and one that values the atmosphere that accompanies it.

6. It should be underlined that image-building efforts in the studied social enterprises are made with varying intensity. The following behaviours can be identified:

- Chaotic and uncoordinated activities, consisting only of meetings with groups of co-operators and customers, which stem from the lack of time and employees who could perform these tasks, as well as disbelief in the effectiveness of PR activities.

- Intuitive rather than planned public relations activities performed by almost all employees of the enterprise, although the heaviest burden rests e.g. on the separate customer relations division and organisation leaders. The activities consist of informing the community via the website about the successful endeavours of the company (awards, competitions, honours), leaders establishing contacts with people who can become allies of the enterprise, production of films and press materials, giving interviews, participation in meetings, fairs, and conferences.

7. The enterprises that intuitively, but at the same time intentionally use various PR tools, note - above all - the necessity for all employees to act, with the simultaneous assumption 
that the most important actions are the responsibility of the organisation's management and leaders. In organisations that declare a lack of human resources for image-building activities, they are regarded as non-priority, complementary, and rather generating costs than profits.

To conclude, leaders are usually responsible for forming the image of social enterprises developing in Poland. However, they do state that they try to engage their entire teams in these actions. That is because they often want to be seen as an entity open to cooperation and valuing the atmosphere which should accompany it. Some entities try to create their image on the basic values represented by social economics, meaning creativity, social goals including those of the local community, not looking for profit or providing social help. Only a few from the researched enterprises were able to answer whether their social image is in accordance with their expectations. Assumptions were rather formed instead of certainty. Whereas, those enterprises which actually try to create a positive image in their surroundings (environment), honestly believe that they achieve good results thanks to maintaining close relations, based on trust and clearness of actions, especially in terms of forming relations with donors. The base is constituted by transparency of actions, and primarily managing finances.

To summarise, research conducted in terms of social enterprises show their rather poor competences in terms of forming the corporate image and PR actions. The most developed social entities often assume that it will be better in these terms when marketing, image, and public relations actions are handled by specialised organisational sections, or individual units. Some of the researched entities believe that they have such a good product that it will sell itself, while others believe that PR actions are not for them, and constitute a form of manipulation which is far from them in terms of the social goals which they intend to achieve.

Finally, an image which will present the enterprise as reliable and providing high quality services, was indicated as the perfect one. In this case, companies often reach for references received from contemporary clients - mostly institutional. The key-words included: reliability, acting in accordance with the law, taking advantage of international management standards (ISO). Furthermore, according to some enterprises, forming the image is impacted by the received awards, granted by public and private institutions. Some entities claim that the image 
is also built by satisfied individual clients - recommending, returning, and supporting the enterprise's social actions.

\section{REFERENCES}

Adamiak, P. (2015). Wizerunek organizacji pozarzqdowych. Raport z badania. Warszawa: Stowarzyszenie Klon/Jawor.

Amin, A. (2009). Locating the social economy. In: A. Amin (ed.), Social economy. International perspectives on Economic Solidarity. London, New York: Zed Books, 3-21.

Bielińska-Kuniszewska, K. \& Demitrewicz, K. (2012). Public relations w NGO. Budowanie wizerunku organizacji pozarzadowych. Wrocław: Sektor 3.

Bogacz-Wojtanowska, E. (2013). Zdolności organizacyjne a wspótdziatanie organizacji pozarzqdowych. Kraków: Instytut Spraw Publicznych UJ.

Bogacz-Wojtanowska, E., Lendzion, M. \& Przybysz, I. (2014). Sukces i trwałość ekonomii społecznej w warunkach polskich. Warszawa: Instytut Spraw Publicznych.

Bukowiec, E. (2005). Działanie firmy za pomocą słów, czyli wpływ formy komunikatów werbalnych na kształtowanie się wizerunku przedsiębiorstwa. In: E. Hoppe (ed.), Public relations instytucji użyteczności publicznej. Gdańsk: SPG, 27-42.

Defourny, J. (2001). From third sector to social enterprises. In: C. Borzaga \& J. Defourny (eds.), The Emergence of Social Enterprise. London, New York: Routledge, 1-18.

Eisenhardt, K.M. (1989). Building theories from case study research. Academy of Management Review, 14, 4, 532-550.

Frączek, A. (2011). Public relations jako narzędzie komunikacji społecznej. Studia Gdańskie. Wizje i rzeczywistość, 8, 116-127.

Henley, T.K., Jr., Wymer, W.W. \& Self, D.R. (eds.) (2001). Marketing Communications for Local Nonprofit Organizations: Targets and Tools. New York: The Haworth Press.

Hubert-Brzezińska, M. \& Olszówka, A. (2008). Współpraca z mediami a tworzenie wizerunku organizacji. Warszawa: Wydawca Fundacja Rozwoju Systemu Edukacji.

Jäger, U. (2010). Managing Social Businesses: Mission, Governance, Strategy and Accountability. London: Palgrave Macmillan.

Jemielniak D., Koźmiński A.K. \& Latusek-Jurczak D. (2014). Zasady zarzqdzania. Warszawa: Wolters Kluwer, 19-51.

Kocoń, P. (2013). Public relations w przestrzeni społecznej. Zarzqdzanie Publiczne 2013, 79-91. 
Kostera, M. (2008). Zarządzanie na rynku doznań. In: M. Kostera (ed.), Nowe kierunki w zarzadzaniu. Warszawa: Wydawnictwa Akademickie i Profesjonalne, 393-411.

Kotas, M. (2014). Wizerunek organizacji publicznej jako instrument efektywnego komunikowania z interesariuszami. In: A. Fraczkiewicz-Wronka, J. Gouchowski \& A. Adamus-Matuszyńska (eds.), Studia Ekonomiczne. Public Relations. Doskonalenie procesu komunikowania w przestrzeni publicznej, 185, 133-141.

Laidler-Kylander, N., Quelch, J.A. \& Simonin, B.L. (2007). Building and valuing global brands in the nonprofit sector. Nonprofit Management \& Leadership, $17,3,253-277$.

Lechat, N. (2009). Organizing for the solidarity economy in south Brazil. In: A. Amin (ed.), Social economy. International perspectives on Economic Solidarity. London, New York: Zed Books, 159-174.

Łukasiuk, M. (2014). PR NGOsów. Komunikacja strategiczna organizacji pozarzadowych. Warszawa: Wydawnictwo Naukowe Sub Lupa.

Mendell, M. (2009). The three pillars of the social economy: the Quebec experience. In: A. Amin (ed.), Social economy. International perspectives on Economic Solidarity. London, New York: Zed Books, 176-207.

Mort, G.S., Weerawardena, J. \& Carnegie, K. (2002). Social entrepreneurship: Towards conceptualization. International Journal of Nonprofit and Voluntary Sector Marketing, 8, 1, 76-88.

Pawlak-Kołodziejska, K. (2011). Kształtowanie wizerunku przedsiębiorstwa za pomocą działań z zakresu public relations. Zeszyty Naukowe Ostrołęckiego Towarzystwa Naukowego 25, 527-539.

Rymsza, M. (2008). The social economy and the third sector. Poland compared to european experiences. The Quarterly on Civil Society. Social Economy, Non-profit Sector and Social Policy: Poland and Europe. Warsaw: Institute of Public Affairs, 4-11.

Smektała, T. (2006). Public Relations w Internecie. Wrocław: Astrum.

Stopczyńska, K. (2014). Wpływ wizerunku kreowanego za pomoca social media na kreowanie postaw lojalnościowych klientów. Marketing i Rynek, 11, 267-275.

Tokarski, J. (1980). Stownik wyrazów obcych. Warszawa: PWN, 808.

Witczak, O. (2013). Nowe media w budowaniu marki i wizerunku przedsiębiorstwa. In: A. Bajdak (ed.), Studia Ekonomiczne. Komunikacja marketingowa: wspótczesne wyzwania i kierunki rozwoju, 140, 80-97.

Yin, R. (1984). Case Study Research. Beverly Hills: Sage Publications.

Young, D.R. (2007). A Unified Theory of Social Enterprise. Working Paper 07-01, Andrew Young School of Policy Studies, Georgia State University, 1-24.

Zappala, G. (2001). From charity to social enterprise: managing volunteers in public-serving nonprofits. Australian Journal on Volunteering, 6, 1, 41-49. 


\title{
EKONOMICZNE I SPOKECZNE KSZTAKTOWANIE WIZERUNKU W PRZEDSIĘBIORSTWACH SPOKECZNYCH
}

\begin{abstract}
Abstrakt
Tło badań. Wizerunek organizacji jest zbiorem subiektywnych wyobrażeń i przekonań, jakie posiadaja o organizacji jej odbiorcy. Na negatywny lub pozytywny odbiór organizacji przez otoczenie zewnętrzne i wewnętrzne wpływa cała działalność organizacji. Dlatego świadome kształtowanie wizerunku i podejmowanie działań z zakresu public relations wymaga korzystania z określonych narzędzi i metod.
\end{abstract}

Cel badań. Celem opracowania jest rozpoznanie sposobów kreowania wizerunku przez przedsiębiorstwa społeczne w Polsce. W szczególności autorki koncentrują się na tym, jaki stosunek do budowania wizerunku organizacji mają liderzy przedsiębiorstw, jakimi metodami się posługują oraz czy badają skuteczność organizacyjna w obszarze kreowania wizerunku.

Metodologia. Zaprezentowane wyniki są rezultatem analizy o charakterze jakościowym. Dane zebrano za pomocą następujących metod badawczych: pogłębionych wywiadów indywidualnych, obserwacji i analizy dokumentów. Badania, których częściowe wyniki tutaj prezentujemy, przeprowadzono w 2012 i 2013 roku w ramach projektu Zintegrowany system wsparcia ekonomii społecznej.

Kluczowe wnioski. Wyniki badań jakościowych dowodza, że pomimo świadomości przedsiębiorstw społecznych dotyczących potrzeby kreowania wizerunku, często nie podejmują one zaplanowanych w tym celu działań.

Słowa kluczowe: przedsiębiorstwa społeczne, wizerunek organizacji, public relations. 